\title{
Radical Proposal for Educational Pluralism and The State's Educational Neutrality Policy
}

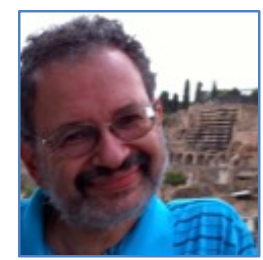

Eugene Matusov

University of Delaware, USA

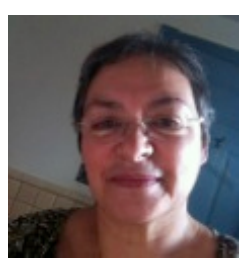

Ana Marjanovic-Shane

Chestnut Hill College, USA

\begin{abstract}
Currently, in institutionalized education, the balance between global and local forces is skewed in favor of the global through the State (and University) monopoly on educational philosophy. We think that the local has to be prioritized over the global in the balance of these forces. In our view, this promotion should occur both in depth (through open pedagogical experimentation and democratization, defining local values, creating a global dialogue), AND in breadth (through providing opportunities for students and parents to join and financially afford it). We propose that education has to be separated from the State. In our proposal, the State should focus on providing financial access to K-12 education for all citizens through redistribution of taxes while constraining itself through pedagogical neutrality: accepting any educational philosophy for public funding. In our paper, we will consider some of many diverse concerns raised by our colleagues in response to our radical proposal of the State's educational neutrality, organized in a question-answer format.
\end{abstract}

Eugene Matusov is a Professor of Education at the University of Delaware. He studied developmental psychology with Soviet researchers working in the Vygotskian paradigm and worked as a schoolteacher before immigrating to the United States. He uses sociocultural and Bakhtinian dialogic approaches to education. Contact address: School of Education, 16 W Main St. University of Delaware, Newark, DE 19716, USA

Ana Marjanovic-Shane, is an Associate Professor of Education at Chestnut Hill College, Philadelphia. She studies meaning making, imagination and creativity in children's play, language and in education from the Bakhtinian sociocultural perspective. Her recent focus are dialogic relationships and democracy in education. Contact Address: 1906 Germantown Ave, Philadelphia, PA 19118, USA

\section{Acknowledgements}

We are greatly thankful to many our colleagues who read previous drafts of our radical proposal for the Educational Pluralism (aka Education 2.0) and raised their concerns and questions: Jayne White, Jay Lemke, Alexander Sidorkin, Paul Sullivan, Beth Ferholt, Anna Rainio, Yifat Ben David Kolikant, Iris Ben David-Hadar, David Blacker, Michal Zellermayer, Peter Rule, Brian Edmiston, Ruth Arber, Ulrike Wolff-Jontofsohn, Werner Wintersteiner, Mariam Orkodashvili, Gail Weinstein, Michalinos Zembylas, Terrie Epstein, and Zvi Bekerman. We want to thank Zvi Bekerman for inviting us to present and discuss our proposal at the Cultural Sustainability, Social Cohesion, and Glocal Education, Jerusalem, Israel, June 16-18, 2013. We also want to thank to Jim Rietmulder and Kathy von 


\section{Radical Proposal for Educational Pluralism and the State's Educational Neutrality Policy}

Eugene Matusov, Ana Marjanovic-Shane

Duyke for supporting our proposal and Kevin Currie-Knight who helped us to develop some of replies in dialogue with his libertarian position on education. We also want to disclose that we have not cherry picked nor weeded out any concern about our State's Educational Neutrality introduced by our generous colleagues: we either tried to modify our proposal or honestly addressed the concern. Finally, we want to thank Mark Smith and Carolina Correa for their editing and feedback on our earlier version of the manuscript.

$\cos \cos 80$

\section{Radical Proposal for the State's Educational Neutrality}

Currently, in institutionalized education, the balance between global and local forces is skewed in favor of the global through the State (and University) monopoly on educational philosophy. Out of all public institutions in democratic societies, educational institutions (public and private, with a few exceptions) remains probably most undemocratic and illiberal. We think that the local has to be prioritized over the global in the balance of these forces. In our view, this promotion should occur both in depth (through open pedagogical experimentation and democratization, defining local values, creating a global dialogue), AND in breadth (through providing opportunities for students and parents to join and financially afford it). We propose that education has to be separated from the State. In our proposal, the State should focus on providing financial access to K-12 education for all citizens through redistribution of taxes while constraining itself through pedagogical neutrality: accepting any educational philosophy for public funding. In our controversial Editorial, we will consider some of many diverse concerns raised by our colleagues in response to our radical proposal of the State's educational neutrality, organized in a question-answer format. We invite our readers to join the critical discussion of our controversial proposal for educational pluralism and policy of the State's Educational Neutrality to support it.

\section{Setting the problem with current educational philosopby monopoly}

We argue that the balance of the local and the global forces in formal educational institutions has to be promoted in depth and in breadth through educational tolerance and pluralism. It has to be promoted in depth through open legitimate pedagogical experimentation, defining local values, and creating a global and local dialogue. Also, it has to be promoted in breadth through providing educationally diverse opportunities for students and parents to join and financially afford it.

Currently, in mainstream institutionalized education, the balance between the global and the local forces is skewed in favor of the global through the State (and University) monopoly on the educational philosophy and prioritization of non-educational goals such as, for example, social cohesion (e.g., Green, Preston, \& Janmaat, 2006). We ${ }^{1}$ argue that the educationally local has to be prioritized over the educationally and non-educationally global in the balance of these forces. The global educational monopoly on institutional educational practice has to be broken. Currently, this global educational monopoly is shaped by a particular educational philosophy of Standards-Based Education (SBE), based on the predefined notion of quality of education and its goals and on the preset and prescribed curriculum. However, even the alternative and innovative educational movements (e.g., constructivist, progressivist, dialogic) view themselves as Benevolent Dictators in their fight for this global educational monopoly to impose their dear educational philosophies on all educational institutions. Coming from the Democratic Dialogic Education For and From Authorial Agency (DDEFFAA) (Matusov \& MarjanovicShane, 2014), we think this is a wrong-headed political and educational goal. Instead, we think the global educational monopoly itself has to be abandoned in favor of Educational Pluralism.

In our view, each educational philosophy has two independent dimensions: 1) partisan-visionary (i.e., how it defines its educational values of "good education") and 2) relationship-power (i.e., how it

\footnotetext{
${ }^{1}$ Here and further on in the essay, "we" is referred to the authors of this article.
} 
views its relationship with other educational philosophies of a diverse degree of disagreement). At the current point in time, it seems that almost ALL existing educational philosophies, - with a possible exception of the Democratic Education philosophy ${ }^{2}$, - seek to impose a monopoly on institutional educational power through convincing all educators and the general public of its value and appealing to the State to enforce and impose its vision on all educational institutions (see Table 1). We implore both all the educational philosophies and the State to abandon their insistence on educational monopoly in favor of educational pluralism. The role of the global has to be mainly limited to providing access to diverse education for all and for protecting the educational pluralism. The global must be educationally neutral and pluralist. The local can and should be educationally partisan and visionary.

Table 1. Two dimensions of educational philosophies

\begin{tabular}{|l|l|c|c|}
\hline & & \multicolumn{2}{|c|}{ Relationship-Power } \\
\hline \multirow{4}{*}{ Partisan-Visionary } & & Monopolist & Pluralist \\
\cline { 2 - 4 } & Transmission of knowledge & $\mathrm{x}$ & \\
\cline { 2 - 4 } & Constructivist & $\mathrm{x}$ & \\
\cline { 2 - 4 } & Progressivist & $\mathrm{x}$ & $\mathrm{x}$ \\
\cline { 2 - 4 } & DDEFFAA & $\mathrm{x}->$ & $\mathrm{x}$ \\
\cline { 2 - 4 } & Democratic education & & \\
\hline
\end{tabular}

Proposal for educational pluralism

The key notion of the global pluralistic approach to education is democratic respect for, tolerance of, and appreciation of others in face of disagreement and misunderstanding. From a dialogic perspective, educational pluralism is based on the notion of inherent dialogism of meaning making (Bakhtin, 1986, 1999; Matusov, 2009; Sidorkin, 1999). Meaning is located not in statements but in the relationship between the interested information seeking questions and serious answers, between diverse ideas and approaches. Paraphrasing Bakhtin's famous statement about the notion of culture (Bakhtin, 1999, p. 301), "Educational approach does not have internal territory but exists on the boundaries with other, often opposing, educational approaches." Thus, meaning of one educational approach exists in a dialogic opposition to another, often conflicting, educational approach. Another argument for educational pluralism coming from DDEFFAA is that overall goal of education is a critical examination of the self, life, world and society, which includes education itself. Critical examination and defining "good education" is a part of education itself - praxis of praxis (Matusov \& Marjanovic-Shane, 2012) - it cannot be predefined. Morson defined critical dialogue as a dialogue, in which everything is "dialogically tested and forever testable." Education, based on the critical dialogue, should test itself and its alternatives, which should be kept as legitimate. Finally, dialogue inherently opposes any actions that are not based on "internally persuasive discourse" (Bakhtin, 1991; Matusov \& von Duyke, 2010).

Paraphrasing the famous motto, wrongly attributed to Voltaire (Guterman, 1990; Hall, 1906), education should hold both partisan and pluralist positions, "I disapprove of your educational philosophy, but I will defend to the death your right to use it in your (publically-funded) school" (Matusov \& MarjanovicShane, 2011). Thus, we maintain both a globalized pluralistic position in policymaking to include all educational philosophies and approaches that are valued and also our own localized particular partisan position - Democratic Dialogic Education From and For Authorial Agency ${ }^{3}$ (DDEFFAA) (Matusov, 2011; Matusov \& Marjanovic-Shane, 2014) - as our goal to further develop and practice our own ideas, beliefs and positions.

\footnotetext{
${ }^{2}$ See Summerhill (Neill, 1960), Sudbury Valley School (Greenberg, 1992), The Circle School (Rietmulder, 2009).

${ }^{3}$ A version of Dialogic Pedagogy.
} 


\section{Radical Proposal for Educational Pluralism and the State's Educational Neutrality Policy}

Eugene Matusov, Ana Marjanovic-Shane

Charles Leslie Glenn raised a rhetorical question underlining this problem of the state's educational monopoly, "How can the pluralism [and democracy] that we claim to value, the liberty that we prize, be reconciled with a 'state pedagogy' designed to serve state purposes?” (Glenn, 1988, p. 12). In our view, publically-supported institutional educational practice should be democratized and pluralized around the globe. To achieve this, education has to be separated from the State in a somewhat similar way as religion has been separated from the State in many democratic countries (Illich \& Cayley, 1992) ${ }^{4}$. The State should focus on providing financial access to K-12 education for all citizens through redistribution of taxes, while simultaneously constraining itself through pedagogical neutrality: accepting any educational philosophy (including SBE, constructivism, dialogic pedagogy, transmission of knowledge, and even religious doctrine) for public funding (Kukathas, 2003).

\section{The State's Educational Neutrality policy}

We insist that the final judge of the quality and usefulness of education should be the learner as much as possible ${ }^{5}$, including her/his right to move away from the enrolled educational services when the learner finds these educational services insensitive to his/her educational needs. Thus, education can become a self-correcting practice, in which the learners vote with their feet in a response to their own authorial judgment of the quality of this educational practice. A practice that is judged and evaluated by its participants, based on their evolving needs, opinions, ideas, desires, and interests, has a non-guaranteed potential to become an open, critical, creative and responsive praxis (Matusov \& Marjanovic-Shane, 2012).

To make quality education affordable for all, while promoting self-correcting educational practices through direct negotiations among students, guardians of younger children and students with some mental disabilities, and educators, it should be supported by public educational neutrality vouchers ${ }^{6}$ funded by the taxpayers. We see good quality education as a basic human right. Good education requires some minimum funding while funding alone does not guarantee good education (actually nothing guarantees good education). In the context of the State's Educational Neutrality, the only indicator of the educational quality is students' satisfaction of their education (mediated by the guardians' satisfaction for young children or mentally disabled students).

Thus, the priority is to provide enough funding for quality education, rather than to equalize funding (Mouffe, 2000). To promote universal financial access to quality education as defined by students, the amount of public educational neutrality vouchers will be determined in the following way. An annual education satisfaction survey will be given to two groups of students: the "poorest" - those who receive only public educational neutrality vouchers; and the "richest" - those who, in addition to the vouchers, also obtain private or public contributions. Roughly speaking, if the average satisfaction of the "poorest" students does not reach a "good level", while the average satisfaction of the "richest" students does, then an adjustment of the vouchers will be needed. When public educational neutrality voucher has to be adjusted, the Federal Government, State Government, and/or Local County Government have to increase the public voucher amount, pending on taxpayers' and representatives' political willingness, other demands, availability of resources, and the priorities of the society (see Appendix below and http://diaped.soe.udel.edu/SEN/?page id=56 for details and calculations). For students with special needs, additional special education vouchers have to be issued.

\footnotetext{
${ }^{4}$ The important discussion of how our radical proposal of reforming institutionalized mass education is similar to and different from other radical proposals like Illich's (1983), Sidorkin's (2009), Dewey's (1966), Holt (1976), and so on is out of scope of this paper.

5 We propose legal guardians for very young children and students with severe mental disabilities; for details, see (http://diaped.soe.udel.edu/SEN/?page id=49)

${ }^{6}$ The important discussion of how our educational neutrality voucher proposal is different from market-based voucher proposals (e.g., Friedman, 1955; Mill \& Collini, 1989) and their practical realizations such the GI bill in the UK and the USA is outside of the scope of this paper.
} 
Furthermore, all legitimate non-educational functions of the current educational institutions should be separated and financed separately in order not to divert the purpose of education - e.g., baby-sitting, teenage supervision, preventing children gangs and delinquency, comprehensive immunization, sorting people for proficiency or other purposes (i.e., summative assessments), providing health care, and so on. For example, if a student decides not to get education, his/her parents have to be provided by another, non-educational, voucher for some non-educational functions valued by the society.

Since educational pluralism respects and values students' freedom of non-participation and noncooperation, genuine education cannot be mandatory and, thus, cannot be forced on students by the State. On the other hand, if a local community values and requires forced, mandatory, education, the State should not interfere by opposing this value either, except in protecting individual students' right to leave these illiberal communities (Kukathas, 2003). Freeing education practices from non-educational functions and goals, regardless of how important and legitimate these functions are, ${ }^{7}$ will ease the societal pressure to make education mandatory (Matusov \& Marjanovic-Shane, 2011).

We hope that the global societal reorganization and democratization of education supported by public funding will promote culturally diverse and innovative educational philosophies, some of which will be rooted in local cultural traditions, new educational values, and experimentation with both institutionalized and non-institutionalized education (e.g., homeschooling, apprenticeship, traditional cultural forms of guidance, student-run educational organizations).

We suspect that in the long run, the global societal support for and spread of the educational pluralism will depend on recognition of its humanistic values, democratization of education, and the growing global economic trends of a shift from skill- and knowledge-based labor/work to agency-based labor/work and leisure (Arendt, 1958; Gorz, 1989; Keynes, 1963). The latter demands and seeks from workers creativity, imagination, innovations, participation in design, consistent exposure to and expectations of the unpredictability inherent in ongoing projects, originality, uniqueness, improvisation, critical thinking, out-of-box thinking, experience with relational dynamics, responsibility, the acceptance of risk, the taking of initiatives, a spirit of entrepreneurship, goal defining, developing new values and new desires, experience with dealing with conflicts of desires, and so on (Anderson, 2010; Collins \& Halverson, 2009; Ford, 2015; Kaku, 2011; Pink, 2005; Zhao, 2009). It appears that finally the society will be able to afford democratization of creativity, making legitimate meaning-making a lifestyle for all rather than just for the elite.

In the rest of our paper, we will consider some of many diverse concerns and challenges raised by our colleagues -23 diverse international educational scholars - in response to our radical proposal of the State's educational neutrality, organized in question-answer format. We grouped these concerns and questions by eight major topics:

1. Distrust in students and their parents/guardians

2. Fear of the "unfit" Other

3. Collapse of social cohesion (Charles, Contreras, Demuijnck, Carranza, \& Linden, 2012)

4. Pains of the transition to educational pluralism

5. Socialist concerns about inequality in and marketization of education

6. Societal imposition on education

7. Libertarians' concerns: "The State who pays the piper, calls the Education tune"

8. Contradictions in your Proposal for the Educational Pluralism

\footnotetext{
${ }^{7}$ E.g. school as custodian, day care, health provider, and so on.
} 


\section{Questions and Answers: Concerns About Our State's Educational Neutrality Proposal}

\section{Distrust in Students' and Their Guardians' authorial judgments about education}

1.1. Question: What about some/all students' (and their guardians') incompetence to judge the quality and the usefulness of their education before they even possess sufficient knowledge for such authorial judgment? Wouldn't this lack of knowledge make them vulnerable to a bad judgment about their own education, and, subsequently, a lack of guidance as the students move away from it? What if students decide to only play videogames, masquerading as their education? What if students from traditional societies choose to learn only about, for example, milking camels? Wouldn't it create a possibility that later in life students may regret that they made the wrong decisions about their own education? Will the students' initial ignorance lock them in their ignorance even more?

Answer: Yes, by definition students are ignorant. That is why they need education. Even more, students are not only ignorant but also do not know exactly how they are ignorant. A medieval German monk Nicolas from Cusa argued that education is not about elimination of one's own ignorance, but rather about illumination of one's ignorance by learning the boundary of one's own ignorance (what he called "learned ignorance") (Nicholas, 1954). In our view, one of the most important areas for this illumination is the education itself and its quality.

In our opinion, radical educational pluralism invites the students to engage in investigation of their own educational desires and values by providing existing ready-made educational options and by encouraging students to create new options and modify the existing ones. The uniqueness of educational practice - as critical examination of the self, life, world and society - in comparison with many other practices is that education begins with a question "what is good for me?" including "what is good education for me?" (Matusov \& Marjanovic-Shane, 2012). This kind of education is about making decisions not based on pre-existing ready-made answers, but on generating new questions, critically evaluating different possible answers, and developing new approaches. We believe that conditions, in which education begins with generating questions and problems, have a better chance to create real opportunities for learning than any State educational monopoly. The State's educational monopoly promotes only one type of answer to the question, "why do I need this education" - "because it is mandatory" and "because it will be useful for you in the future, trust us!" We argue that genuine education only occurs when students are engaged in meta-inquiries of why they need education and what is good education for them. These meta-inquiries about education itself are only possible when students make decisions about their own education, when they are free to participate and, thus, to not participate in it, when they are the final authority for their own learning, and when education is free from pedagogical coercion and pedagogical violence. "You can lead a horse to water, but you can't make it drink!... Forcing students to learn is a lost cause..." (Klag, 1994, p. 1).

Still, what about a situation, in which students' ignorance would lead them in bad decision making about their own education, an educational "dead end" of dogmatic, ignorant, brainwashing, or just shallow transmissionist "education"?! We think that neither the status quo of educational monopoly nor educational pluralism can predictably guarantee success in education in this regard. However, we argue that educational pluralism is a better solution. It is because authoritarian and shallow "education," imposed on students, often (but not always) robs students from their educational activism and/or creates students' resistance even in ignorant students. And with the help of resources that educational pluralism provides, students would be able to escape these oppressive educational establishments at any point. In these cases, the self-correcting feedback loop of the practice will work. We expect that when the educational pluralism becomes a culture, the meta-inquiries of "why I need education" and "what education is good for me" would involve people in examination of diverse educational alternatives before they make their educational choices. 
However, what about students who enthusiastically and actively embrace socialization in authoritarian and shallow "education," embrace "pure entertainment", or develop apathy which paralyzed their ability to escape from these authoritarian and/or shallow educational environments?! In our view, we have to live with this possibility. Nothing can be done to completely prevent all negative consequences of students/guardians' bad decisions. The price of freedom and the essence of the freedom are in the people's right to make their own mistakes and even to experience abuses of their freedom. Risk-free, abuse-free, and mistake-free freedom is a misnomer, it does not exist. Unfortunately, bad decisions can and will still happen in our proposal for educational pluralism. People can become remorseful due to their missed educational opportunities. In our view, it is just that there is no alternative to freedom to learn. It is better to miss an available educational opportunity than to close an educational opportunity though alienation to academic learning as happens far too often now. Remorse for missed educational opportunities is in itself already education in action, although it is not necessarily safe and ideal learning.

We see two types of student ignorance that have to be treated in different ways. One type of ignorance may be threatening to students' life and well-bring. This concern is important and legitimate but, we argue, it is not educational and has to be separated from education. We think that not just any learning is educational. For instance, if one saw a group of children reaching to eat something poisonous (e.g. a good looking, but a poisonous mushroom), it would not be safe to just leave them to their own authorial judgment - they should be prevented from making a fatal mistake even by force. This kind of life-threatening ignorance should be a matter of ethical and responsible treatment of young children, youth and other people who for any reason are not in a position to make a good authorial informed judgment in a life- or wellbeing-threatening situation. Guardians who provide protection (baby-sitting, teen supervision, etc.) need to create safe environments to prevent physical and psychological harm. It is sometimes necessary for a child (youth and or adult) to trust someone else to guard and guide them, before they know better. However, we do not see this kind of epistemological trust and almost unconditional obedience ("just do what others tell you to do!") as having an educational value in itself unless it becomes a subject of educational questioning. Learning safe and appropriate behavior without understanding the reasons for it is a matter of training, rather than education. But, it can become education when life safety is investigated with the student. In general, there are many legitimate and important social functions and needs that are non-educational in their nature - they can be promoted and even prioritized at times by the society but should be separated from education.

On the other hand, another type of ignorance may lead a student to experience no life threatening "errors" and/or "mistakes." We see that kind of ignorance as an excellent material or condition for education. When a person notices that their knowledge, beliefs or opinions are not anymore "correct", and starts to doubt that he or she "knows better", it is an exact moment when education begins, i.e. he or she is suddenly moved to learn more about a particular issue,

Contemporary pedagogy, the 'active school', and innumerable experiences in this subject teach us that if something is not acquired by experience and personal reflection it is acquired only superficially, with no change in our thought. It is in spite of adult authority, and not because of it, that the infant learns. Hence it is to the extent that the intelligent teacher knows when to step down as a superior and to become an equal, when to engage in discussion and to require proof rather than merely to make assertions and compel morally, that the traditional school has rendered its services (Piaget \& Smith, 1995, p. 204).

It is never too early or too late for education - education happens when a student recognizes her or his ignorance and asks a real question to which he or she is interested to get a relevant answer. Education is about learning about one's own ignorance and its limits.

Dialogic Pedagogy: An International Online Journal | http://dpj.pitt.edu DOI: 10.5195/dpj.2016.170 | Vol. 4 (2016) 


\section{Radical Proposal for Educational Pluralism and the State's Educational Neutrality Policy}

Eugene Matusov, Ana Marjanovic-Shane

There is also a possibility of misjudging students' ignorance. Outside observers may disvalue certain activities - for example, students' exclusive playing of videogames, fishing, partying and having fun, being interested in fashion or pop culture, playing soccer, and so on. Some proponents of the Democratic Education movement (e.g., a founder of the Sudbury Valley School, Dan Greenberg, 1992) argue that these students will eventually get tired and get over these unproductive activities in the long run. We respectfully disagree, however, that this will always be the case for all students. Indeed, there may well be educational value in students' exclusive engagement in practices that many outside observers may disvalue. These observers may change their mind about the value of the students' prior activities later on, when they learn that the former students became designers of videogames, soccer players, or famous entertainers with multimillion incomes. Similarly, exclusive learning of some traditional cultural practices like milking camels is a legitimate educational activity chosen by students. Learning is a future-oriented process and the future is always unknown, diverse, and unpredictable. Learning has to be meaningful for the students or it stops being learning at all. We argue that learning is a by-product of students' ontological engagement in socially valuable (but at times contested) practices (Matusov, 2009). Deciding what social activities are valuable or not is a part of education itself for each student and should not be regulated.

In our view, although these negative developments cannot be completely prevented, we see some corrective counter forces at work that can minimize the negative power of this development. These students will live in a broader society with educational, informational, social, and political pluralisms that may penetrate both the students' consciousnesses and their oppressive educational environments. Another self-correcting mechanism is "the ontological tests" of these oppressive educational environments by the life itself. Finally, neither students nor the guardians of young children need to make their educational decisions in solitude without an emerging culture of assistance of other people and sources, although the "epistemological authority" of these "expert sources" about quality education is never guaranteed either. Thus, again we hope and rely here on "an invisible hand" of critical dialogue and the attraction for people to participate in it (Bakhtin, 1999).

\section{Fear of the "Unfit" Other}

2.1. Q: What about the separation of Church and State? Educational neutrality vouchers could promote religious education and break this separation.

A: First of all, we think that the majority of conventional public schools are essentially religious because they promote a "civic religion" of authoritative dogmatism (Collins \& Halverson, 2009). For example, when we asked many of our undergraduate students how they know that the Earth is round they said, "It is written in the textbook." Yes, it's not Jesus or Moses but it is science and school authority. In our view, the intellectual and pedagogical result can be nearly the same: truth is based on a belief in the authority.

Second, religious people pay the same taxes as secular ones. They have to have the right for education in whatever way they define it. They should have right to live according to their conscience, guaranteed by a liberal State (Kukathas, 2003). Why should they have to subsidize those with secular beliefs? Is it because secular people are right and religious people are wrong?! Let's have equal rights for education to be "delusional" or "righteous," and have the public pay for it (i.e., all of us!). Since it is up to the students to make a decision about their education, there should be neither any discrimination by the State nor support for any particular religion or its absence (in accordance with the US Constitution, for example).

\footnotetext{
${ }^{8}$ i.e., a test that comes from a person experiencing the negative situation and critically evaluating the experiences rather than an intellectual contemplation and critical evaluation of a hypothetical possibility.
} 


\section{Radical Proposal for Educational Pluralism and the State's Educational Neutrality Policy}

Eugene Matusov, Ana Marjanovic-Shane

2.2. Q: What about hate groups like KKK, terrorists, or Nazi Education?

A: Although we agree that some or all hate groups, plain criminals, and terrorists are a great problem for the society, in our opinion, this should be solved on the level of laws and legality and not through limiting educational pluralism for all. In defense of the liberal democratic society, it is OK to limit educational rights for groups that are outlawed. Unless these groups are outlawed and their practices proclaimed illegal, the principle of educational pluralism has to be preserved for all - i.e., no discrimination against such groups' education can be or should be made.

2.3. Q: What about Illiberal, Undemocratic elements, who are legal, like Religious Fundamentalists, Racists, Nationalists, Neo-Nazi, Fanatics, Totalitarianists -- people whom "liberal, democratic, we" fear and loathe, whom "liberal, democratic, we" want to limit and suppress (at least), with whom "liberal, democratic, we" think any dialogue is impossible (i.e., the Ultimate Other, with whom dialogue is absolutely impossible)? Will they take advantage of educational pluralism? Will your pluralist proposal help them ultimately take control over the society like what historically happened in Germany in 1933, when the National Socialists (Nazis) came to power through the democratic pluralism of the Weimar Republic, ultimately leading to the Nazis abolishing the Weimar democracy? Can educational pluralism weaken and eventually kill a liberal democratic society and State, and your own liberal democratic educational project?

A: On the contrary, we see the main role of the (liberal, democratic) State in our proposal to protect educational (and political) pluralism by repressive force and means (i.e., legislation, courts, police, army). In our view, it is not the role of educational institution to engage in an oppressive function of the State. As the history shows, the political fear and threat coming from totalitarian groups are real but educational pluralism should not be sacrificed preemptively in addressing it. Our defense of the educational pluralism in face of a totalitarian threat is similar to defense of freedom of speech, freedom of assembly, freedom of religion, and freedom of political discourse that can also be abused by totalitarian groups and have to be protected by the State. On the other hand, we see defensive powers of a liberal democratic State as legitimate, which may legitimately interfere with education. This conflict must be resolved by democratic legislative and judicial processes with the framework of a national liberal democratic Constitution.

\section{Collapse of Social Cohesion}

Glenn defined historical public school agenda, supported by the political left and the right, as, "the deliberate effort to create in the entire youth of a nation common attitudes, loyalties, and values, and to do so under direction by the state" $(1988$, p. 4). Since our proposal for the state's educational neutrality rejects this agenda, what if the unity in a larger society collapses under the condition of educational pluralism, leading to fragmentation of the society through various types of segregation? We see a few different concerns within this larger category regarding the types of segregation and conditions for the collapse of social cohesion. Let us analyze them one by one.

3.1. Q: What about fragmentation of the society through voluntary segregation (coming from students)? A: Well, fragmentation and voluntary segregation -- guaranteed freedom of assembly and freedom to leave an assembly -- is an essential part of any liberal, democratic society (Kukathas, 2003). Concerns about promoting social cohesion, as valid societal concerns, are contested and outside of the function of education (at least from our partisan DDEFFAA vision of education). In our view, self-segregation of educational institutions based on a particular educational philosophy is legitimate, e.g. all-girl (or all-boy) schools, Black universities, athletic schools, religious schools, Montessori schools, Democratic schools. etc.

We acknowledge that school choice and market vouchers were historically used to oppose forced racial integration in the United States by several Southern States' racist governments (Carl, 2011). These 


\section{Radical Proposal for Educational Pluralism and the State's Educational Neutrality Policy}

Eugene Matusov, Ana Marjanovic-Shane

states provided vouchers to all parents (both White and Black) so they could submit them to private schools. It gave opportunities for some White parents to place their children in private racially segregated schools. These choice policies allowed parents (and students) who wanted to be racially segregated to remain segregated. In our view, a democratic liberal society always allows voluntary segregation. Currently, predominately Black educational institutions based on voluntary racial segregation still exist in the US. The voluntary segregation always present societal challenges and benefits. It is the forced segregation (and forced integration) that present bigger problems, in our view.

3.2. Q: What about forced segregation coming from the educational organization and providers (e.g., potential students are weeded out via testing, age, entrance exams, or social group filters)?

A: We don't know. This is a tough call! We need advice from legal scholars, from court decisions, and/or from democracy (e.g., people vote for a solution) on a case-by-case basis taking into consideration the severity of the societal problems and their history.

3.3. Q: Will educational neutrality vouchers and educational choices promote homogeneity, fragmentation, and voluntary segregation?

A: Yes, probably, in some cases. This is a good concern. The problem is that the price of forced integration is alienation and violence. In our view, the issue is in the price of social engineering, coercion, and violence behind it. Some voucher schools will be geographically based, probably creating "bubbles" of certain comforts and homogeneities, and some not. That is OK, as some people are "dwellers" interested in comfort provided by homogeneity, some are "nomads" interested in challenges and opportunities provided by diversity, and some are in between.

3.4. Q: Political democracy and political pluralism force diverse people in a contact zone with each other through their fight for power and control over the State, which promotes a dialogue among them (but does not guarantee it). In contrast, your pedagogical democracy and pedagogical pluralism educationally fragments the society into opinionated, self-contained, at times even aggressive, ideological "bubbles" and, thus, diminishes opportunities for a dialogue, no? For example, some Muslim communities in Germany do not want their children to study about the Holocaust and socialize their children in AntiSemitism (Wolff-Jontofsohn, 2013). Shouldn't these problems be remedied by an imposed core curriculum in public education?

A: We agree that fragmentation in society is a potentially serious problem and that some but, by no means all, educational practices under our educational pluralism may lead to fragmentation. However, we have two main issues with this critique of educational pluralism: 1) Would alternatives to educational pluralism based on forced educational integration better solve the problem of societal fragmentation? and 2) If so, should educational pluralism and, thus, genuine education examining life and the world (in our definition of education), be sacrificed for a legitimate societal concern with societal fragmentation?

In our view, the first question is really empirical and not as obvious as it seems. There has been some empirical evidence that voluntary educational integration of magnet schools ${ }^{9}$ is more effective than forced educational integration based on school desegregation busing policies ${ }^{10}$ in the US (Rossell, 1990). We think, but it should be studied further, that on average forced educational integration creates more societal fragmentation than educational pluralism will create. Forced educational integration creates alienation, disinterest, resistance, repulsion, and, thus, strong disengagement from imposed education disengagement with its mighty centrifugal forces as students' agencies search for their creative meaning

\footnotetext{
${ }^{9}$ In the U.S. education system, magnet schools are public schools with specialized courses or curricula to attract diverse population of students for volunteer integration https://en.wikipedia.org/wiki/Magnet school.

10 "Desegregation busing in the United States (also known as forced busing or simply busing) is the practice of assigning and transporting students to schools in such a manner as to redress prior racial segregation of schools, or to overcome the effects of residential segregation on local school demographics" https://en.wikipedia.org/wiki/Desegregation_busing.
} 
of self-realization and move away from each other (e.g., Willis, 1981). In contrast, educational pluralism promotes centripetal forces by creating conditions for freedom of exploration and interests in others conditions that may or may not realize.

Our educational libertarian colleague Kevin Currie-Knight made the following important argument in response to this concern, "Even if fragmentation is a bad thing, there is a tradeoff here between allowing individual liberty (and the possibility of fragmentation) and disallowing individual liberty so that we can ensure homogeneity. So, at very least, anyone who argues that we want to educate so that we all have certain educational experiences in common must be prepared to argue that individual liberty is less important than homogeneity."

Let's bring another political example. Based on the historic fears, both states of Germany and Austria have banned neo-Nazi parties, their public political discourses, and literature. In contrast, in the United States these neo-Nazi parties, public political discourses, and literature are legal, which allows, but does not require, a public dialogue between "us" and "them" about ideological and moral tensions. In the United States, neo-Nazi groups are relatively weak, while in Germany and Austria they are relatively strong. We wonder if free, non-forced, public discourse glues society together and deals better with distractive forces of totalitarianism and bigotry.

Thus, educational pluralism and freely minded education itself do not need to be sacrificed preemptively, before being tried and carefully studied, for fear of societal fragmentation. In our view, social cohesion must not be imposed through education.

\section{Pains of Transitions to the Educational Pluralism}

4.1 Q: How can the society start the transition from the current authoritarian system based on accountability to the new democratic system based on the State's Education Neutrality, educational pluralism, and self-correcting practice?

A: This question should be better addressed by public policy analysts and educational economists. We roughly envision this process in the following way. There should be preparation time allocated after the Congress and the President (e.g., in the US) sign a new education bill authorizing the new democratic system based on the State's Education Neutrality. This time will be used on building new (very small) governmental bureaucracy for educational neutrality vouchers and diverse public schools - regular, magnet, charter and so on - should use this time for planning what they want to do. Then, all public schools and school bureaucracies will be closed and some will be reopened if they get enough educational neutrality vouchers from students and parents of younger kids. Also, new educational organizations and providers will emerge. However, there can be a transitional period of running two system in parallel, with one fading and the other growing. During this period all schools and educational providers will be asked to write their educational charter in preparation for the transition if they want to receive the public educational neutrality vouchers.

There is an important and interesting empirical question of whether the existing public funding is enough for our proposal. On the one hand, it may be not because probably more students become covered by the public education fund then now because public educational neutrality vouchers can be used by private providers and private schools. But on the other hand, we and some other scholars expect big saving on cutting the state educational bureaucracies on different levels (Sidorkin, 2009). We think that economists and social scientists can help to assess the total costs. Additional funding resources may be needed to be allocated by government assemblies for the transition process and/or possible deficit after the transition.

4.2. Q: Will this radical transformation based on the State's education neutrality kill public schools (in their current form as state-run bureaucracies)?

Dialogic Pedagogy: An International Online Journal | http://dpj.pitt.edu

DOI: 10.5195/dpj.2016.170 | Vol. 4 (2016) 


\section{Radical Proposal for Educational Pluralism and the State's Educational Neutrality Policy}

Eugene Matusov, Ana Marjanovic-Shane

A: All voucher-based educational institutions (e.g., schools, homeschooling, educational agencies, educational cooperatives, learning circles, self-studies, and so on) will become public because they will be financed by public money of taxpayers. Public schools, - i.e., publically financed schools, - do not need state bureaucracies to run. However, some current public schools will probably have to transform one way or another from being a part of a larger state-run bureaucracy to becoming a self-standing and self-governing school, based on negotiation with the students (mediated by parents for younger children) and on the self-correction processes answering to the students. Not all of the current public schools will probably be able to survive. If existing public schools are perceived by a financially sufficient number of students as good, these public schools will probably survive. If not, they will not be able to keep up with student-choice education - the students will pull out their public educational neutrality vouchers from them. Those public/state-run (and private-run!) schools will be forced to choose either to change or to close.

But, is this Social Darwinism of survival of the fittest? In our view, it is not because it is about good and not the fittest (or strongest). Does anyone want his or her children to attend a bad school? We do not think so. As Dewey (1915, p. 19) wrote, "What the best and wisest parent wants for his own child, that must the community want for all of its children. Any other ideal for our schools is narrow and unlovely; acted upon, it destroys our democracy." Of course, what is good or bad can be contested, which is fine in our proposal since we insist on educational pluralism and the State's educational neutrality. If the students find a school to be good, it will be fine. However, if nobody or very few people like it, it will die without funding. In our view, it is a self-correcting process embedded in educational pluralism rather than Social Darwinism leading to monopoly and monologism.

In fact, all existing systems of public education are based on public vouchers, - i.e., a redistribution of funds for education through taxation. The issue is who exactly gets these public vouchers. Currently, these public vouchers go to school district bureaucracies. In the State's Educational Neutrality policy, the public educational neutrality vouchers will be going to directly to students (or their guardians). Costs calculated per child, the public vouchers go to school district bureaucracies that channel them to particular schools (in the US). We suspect that in other countries it is somewhat similar.

We think that the public is people and not the State or the State bureaucracies. So, why not trust people with their decisions of what is good for them using their money?! We want to abolish totalitarian schools, not public schools ${ }^{11}$. All schools are public in that they are supported with public money. We want to abolish the current state of imposition of technological standards-based education on all except the rich, who can pay for their own schools. We want to abolish any educational monopoly driven by any educational partisan philosophy (including our own favorite DDEFFAA) and promote the right of access to good education for all - not imposed equality of mediocrity and misery. We see much more fairness and democracy in our educational neutrality voucher proposal than in the existing totalitarian standard-based school system of accountability and alienated learning.

4.3. Q: What about teachers? Their professionalism? Their position and protection of their job and conditions of work (i.e. what about teacher unions)? Will the revolution of the State's Education Neutrality worsen the teachers' professionalism and conditions of teachers' jobs?

A: We suspect good teachers will flourish and the State's Education Neutrality will raise teachers' professionalism - based on the real life feedback about their teaching that will come from the students. However, the same feedback also may and will worsen conditions of teachers' job stability rather strongly. Some teachers will lose their jobs if there is no demand or they won't be appreciated by the students. To ease the transition, the State may need to assist willing teachers to educate themselves in a new

\footnotetext{
${ }^{11}$ Currently in the USA, we see two opposing trends of public education: top-down standardization (e.g., the "No Child Left Behind", "Rise To the Top", "Common Core" reforms) and bottom-up diversification with the spread of charter and magnet schools, especially in cities.
}

Dialogic Pedagogy: An International Online Journal | http://dpj.pitt.edu DOI: 10.5195/dpj.2016.170 | Vol. 4 (2016) 


\section{Radical Proposal for Educational Pluralism and the State's Educational Neutrality Policy}

Eugene Matusov, Ana Marjanovic-Shane

educational environment with providing TEACHER EDUCATION vouchers to preserve their jobs or find new ones (although it will never guarantee the preservation of the jobs in each and every case). The teacher tenure may or may not be destroyed, depending on the educational institution and its resources and philosophy. As to teachers' salaries, this issue has to be studied by educational economists. The salaries may even be raised (see 4.1), but we don't know that for sure.

As to the teachers' unions, they will be forced to reorganize, no question about that, but they probably will survive (like actors' union without protection of job but fairness, pensions, legal matters, and so on). In our view, in addition to teachers' unions guarding their job conditions and well-being, teachers need to develop professional organizations with different and at time conflicting agendas: 1) a teacher union focusing on the teachers' rights, job security, benefits, salary negotiation, safe job conditions, legal protection of teachers, and so on and 2) a teacher professional organizations focusing on professional improvement and advances of the teaching practice. These two important functions can be at time in accord and at time in contradiction with each other and require separation of their legitimate agendas (Goldstein, 2014). Currently, the teachers' unions include the second functions and they have secondary priorities in the hierarchy of concerns and are often overruled by the first functions. That is, in our view, why we may see cases of an excellent novice teacher being laid off to secure the seniority even of a mediocre teacher.

4.4. Q: Can we accept your pluralist theory of Dialogic Pedagogy but develop a different proposal, keeping a safeguard of benevolent monopoly on educational philosophy or some kind of Limited Educational Pluralism or Gradual Educational Pluralism without committing to your radical, sweeping, untested, and scary proposal for your "educational pluralism" full of potentially bad, painful consequences? Why don't you use your intellectual muscle to develop a way of spreading your Democratic Dialogic Education For and From Authorial Agency (DDEFFAA) that we like as the best way (or, let's say in a politically correct way, "a better way") of education on more and more students? Why do we need to willingly give "them" resources for education to the pedagogical practices that we dislike and despise and, thus, promoting monologic and oppressive types of "education"?

A: We envision "Limited Educational Pluralism" (LEP) as a situation when certain "legitimate" educational philosophies will be allowed and supported by the State but some others will be not. Students or their parents will be financed by taxpayers' dollars to attend educational institutions and settings (e.g., homeschools) that have committed to the legitimate educational philosophies. However, other educational institutions and settings will be not approved for funding (e.g., "dogmatic" educational philosophies, the religious, the "intolerant", and so on). Special federal, state, and local governmental educational boards can make these political decisions on behalf of their taxpayers' constituencies: a) which educational philosophy to finance and which not and b) whether an educational institution or setting complies with legitimate educational philosophy or not in its practice. This differs from our "unfettered" educational pluralism that is limited by the legal system, not by an arbitrary political decision of public philosophical preferences.

First of all, we definitely see a step forward in this limited educational pluralism from the current stage of the State educational monopoly. It will also promote more debates on educational values and engage students in decision making about their education (if this version of LEP directly gives students the decision making power and not their guardians - especially for older students, of course). In our view, LEP is an acceptable temporary compromise and a significant improvement in the educational practice, moving it in "the right direction." LEP could be a transitional phase toward full Educational Pluralism.

However, we see at least three major objections against the LEP approach if permanently established. First, in LEP, political boards and taxpayers will limit students' decision making about "good" and "bad" to legally allowed educational philosophies and practices and thus limit the quality of their education as understood through praxis of praxis - i.e., the student's examination of values of his or her 


\section{Radical Proposal for Educational Pluralism and the State's Educational Neutrality Policy}

Eugene Matusov, Ana Marjanovic-Shane

own educational values and deciding what is the best for the student him or herself (Matusov \& Marjanovic-Shane, 2012). Second, all taxpayers should be allowed to use benefits of their educational tax within the limits of the law. Third, LEP creates a disparity between rich students, who have more educational choices outside of public schools, and poor students, who do not have them. Thus, by default, rich students are engaged in higher quality of education defined as praxis of praxis.

Regarding this proposal for a "Gradual Transition to Educational Pluralism", we think that as political conditions in a country mature for Educational Pluralism, it is fine to transition gradually when the State Educational Monopoly becomes weakened and the overall educational practice is moving toward Educational Pluralism through creative experimentation.

4.5. Q: Is "our" society (e.g., US, UK, Russia, Israel, South Africa, New Zealand, China, Vietnam, etc.) really ready for unfettered educational pluralism? If not, what are right conditions, traditions, and transitions for educational pluralism? Is educational pluralism right and doable for all societies?

A: We agree that the right historical, political, cultural, economic, and social conditions are needed for the State's educational neutrality. Educational pluralism is doable when it can be established through democratic and liberal political processes: voting, judicial decisions, legislation, rule of law, and free political dialogue. It should also have enough economic resources for good quality of education for all. In our view, educational pluralism is the only educational principle that is compatible with a Constitution in a democratic society (but other people may disagree) and with a liberal society and a liberal state. We think that ideas of the educational pluralism will be more supported in societies with long democratic traditions and liberal tolerance with dissent of the ultimate illiberal, undemocratic, other. We suspect that educational pluralism will be more supported in post-skill and post-knowledge, agency-based societies and economies (Zhao, 2009) with open access information, and we see trends toward this development around the globe (especially in "economically developed" societies, although this is a painful process).

\section{Socialist Concerns about Inequality in and Marketization of Education}

5.1. Q: Will education be commercialized, treating students as consumers? Will a capitalist market economy distort your vision of education with its educational neutrality vouchers and self-correcting educational practices?

A: Yes. There is no doubt about that, as the capitalist market economy does this corruption with art, health care, and other practices. However, capitalist market distortion and corruption of the education is better than the feudalistic pedagogical coercion and violence of the current totalitarian school system (Sidorkin, 2002, 2009).

We see at least two dangers of commercialization. One is deceptive advertising, which can be curtailed by lawsuits, students walking away, and bad publicity and reputation. The other danger is more serious; some educators may try to please students without educating them much. This could create a feel-good industry of junk education (e.g., "edutainment ${ }^{12 "}$ ). This is by far more serious problem because it disrupts a self-correcting feedback loop.

This problem is not new. It exists in art, food, medicine, and other industries and practices. What usually curtails (but not eliminates) this parasitic tendency of capitalism are two counter-currents: 1) people often get tired and bored with empty pleasures, 2) people get exposed to something outside of their immediate "bubble" and they want to move there and experience some new aspects of life. Also, this problem can and should be a part of a public political debate as it is in other industries and practices, like, for example, in the current health care debates in the US.

${ }^{12}$ See, for example, http://www.nytimes.com/2015/03/20/education/turning-to-education-for-fun.html? r r=0

Dialogic Pedagogy: An International Online Journal | http://dpj.pitt.edu

DOI: 10.5195/dpj.2016.170 | Vol. 4 (2016) 


\section{Radical Proposal for Educational Pluralism and the State's Educational Neutrality Policy}

Eugene Matusov, Ana Marjanovic-Shane

5.2. Q: How is this educational pluralism proposal different from the market-based school-choice voucher reform that has been tried on a local basis in many countries?

A: In our view, there is a HUGE difference between our radical proposal for the Educational Pluralism, on the one hand, and existing market-based voucher-choice school experiments (e.g., Friedman, 1955) and the past practices, on the other hand. As far as we know, all tried experiments have so far been embedded in the existing imposition of the technological standards-based and accountability-based education through the State's monopoly on education. In the existing market-based voucher schoolchoice reform, parents often make choices of schools with their vouchers that lead to better outcomes for their children - in terms of societal currencies such as examinations, employment prospects, upward social mobility, grades, test scores, etc. It is still a monologic system of imposed values - the freedom is about how to get a better pathway to these imposed preset values (Bolick, 2003; Friedman, 1955; Lauder, 1999; Nock, 1949) $)^{13}$. Usually educational voucher reforms are supposed to provide instructional diversity and flexibility to better serve to and to better achieve the goals of the educational monopoly on educational values through the system of compulsory education. Currently, this educational monopoly is defined by the standards-based education. In our radical proposal, we argue for plurality of educational values that allows both freedom of educational path (i.e., instruction) and freedom of educational destination (i.e., curriculum).

Finally, proponents of the voucher and school choice market-based reform often argue that the quality of education will be established by market competition (e.g., Friedman, 1955). We disagree with that since a plurality of educational values establishes plurality of what quality in education may mean, thus eliminating competition and promoting diversity. We do agree that the market can be useful for creating a self-correcting loop but we think that it can happen only in a regulated market. For example, currently, many universities have established educational monopolies within "free" educational markets of higher education. We think that like in economy, unregulated or poorly regulated educational markets can lead to cartel-like monopolies. State regulation protecting and defending educational pluralism is needed. For this reason, we are not unfettered market libertarians.

5.3. Q: Will this proposal for the State's education neutrality destroy equal opportunity for education? Isn't liberty a prize that we only achieve after winning the battle for equality?

A: In our view, the State should NOT be in the business of equalizing financial opportunities for education. We are against equality or even equity as the primary concern guiding education. Not only it is unrealistic, but it is really dangerous. Excessive equality is often even more dangerous than excesses of inequality, leading to suicidal and homicidal totalitarianisms because at least the former breads diversity. We think that liberty does not start with equality or even equity - the Old Left is wrong about that (Mouffe, 2000) as it has not learned much from the tragic lessons of the 20th century yet. As the 20th century has painfully shown us, oppression by excessive equality is MUCH WORSE than oppression by excessive inequality, judged by the unprecedented scale of misery, crime, and death by the totalitarian Communist and Fascist regimes, which tried and successfully reduced inequality on a mass scale (both economically and politically). Liberty does not come or start with equality (or equity) but with respect for and appreciation of diversity/otherness and respect for the broadening of minimum universal human rights (Kukathas, 2003). Both extreme equality and inequality are oppressive and have to be avoided as our proposal suggests. However, our proposal does not make the situation perfect or eliminate all terrible abuses but rather jumpstarts a process of making the situation a bit or a lot better (although, probably, still messy and unjust) by empowering people for action.

We are not concerned about "equality-based fairness" or everybody having "the same funding" or "the same opportunities" (i.e., equity). Not only is this an impossible myth, in our view, but it is not

\footnotetext{
${ }^{13}$ For an exception see Goodway (2006), who argues for the participants defining their own education in a market-based schoolchoice voucher proposals.
} 


\section{Radical Proposal for Educational Pluralism and the State's Educational Neutrality Policy}

Eugene Matusov, Ana Marjanovic-Shane

desirable either. We are concerned about the minimum being good enough and moving up - raising minimum human rights (Gorz, 1989; Markoff, 2015; Rifkin, 2014). If somebody has more than the minimum - great, as it promotes further innovations and experimentations! It can set the goal for others and redefine what "being good enough" means. As a writer William Gibson said, "The future is already here - it's just not very evenly distributed." Fighting with an unevenly distributed new good is fighting with the future of this good. The issue is not to eliminate the future from the present by making everybody equal (i.e., misery for all) but to make it more evenly distributed as soon as possible by moving the minimum up. We try to address the issue of the growing gap between the poor and the rich in our proposal by raising minimum voucher funding based on the assessment of the expenses of satisfied students.

When it comes to access to QUALITY education, it is not a matter of equality or degrees of variability, but a matter of a basic human right - and this right must be defined by the student as education that is meaningful to her or him!!! After all, in our opinion, meaningfulness (to the student) is the only measure of the educational quality. Today, while many students have access to "education," a very small number of students have an access to education that is to a certain degree more meaningful to them. But, many, many more students can only access what to them amounts to less meaningful or even completely meaningless "education". The majority of the students have to spend a good part of their lives (12 years + ) in situations that are not only meaningless and distressing but are socially and psychologically harmful in situations of psychological and social suppression equivalent to a psycho-social desert (i.e. total personal meaninglessness, becoming "academic zombies", Matusov \& Brobst, 2013).

5.4. Q: What about persisting inequality? Richer states, richer counties, richer parents can pay for better education (although, what does it mean "better education"?) or at least for more educational resources.

A: Yes, we live in a capitalist society based on economic, social, and political inequality and, thus, education will be affected by it. The question is if this proposal will decrease or increase the existing inequality and in what way. We suspect that based on our Proposal, when rich parents raise funding for their children's education, they may push for increasing value of educational vouchers (see Appendix), pending on the political will and economic resources of the democratic liberal society.

5.5. Q: Education is a public affair in the interest of the society. It's curriculum and instruction have been decided by democratically elected public representatives (e.g., by Local School Board in the US). What is wrong with that?

A: We argue that education and learning (which are not the same according to our DDEFFAA partisan vision) are ALWAYS primary private business of the learner because it is the fundamental human right based on personal meaning making. Pedagogical decisions cannot be delegated to a democratically elected representatives, in our view. Neither the society nor its democratically elected representative cannot and must not decide what is good for each individual learner to learn and how to learn it to make this learning meaningful for the learner. The social concerns and pressures (e.g., job availability, credentialism) can be communicated to the learner but must not be imposed on him or her. Nobody can know what is best for a particular learner in the unknown future.

\section{Societal imposition on education}

6.1. Q: Shouldn't forces and players outside of education legitimately shape education? What about legitimate concerns by employers and/or by the general public about students' competences necessary for: workplaces, skillful and informed democratic participation in the society, competition for getting good jobs, upward social mobility, and so on (see Labaree, 1997)?

Dialogic Pedagogy: An International Online Journal | http://dpj.pitt.edu DOI: 10.5195/dpj.2016.170 | Vol. 4 (2016) 


\section{Radical Proposal for Educational Pluralism and the State's Educational Neutrality Policy}

Eugene Matusov, Ana Marjanovic-Shane

A: First, we insist that all social demands on personal education -- at the end of the day, education is always personal and particular -- should be viewed as contested and problematic for many reasons. The primary reason, in our view, is that education involves meaning making process, which is always personal and it is a fundamental human right. The secondary reason is that considering what is good for a particular student in the past, present, and future is the primary business of the education process itself. The tertiary reasons are that:

a) social forces and players can never know well what is good for a particular student or even for the societal future itself (the future is never fully predictable, unified, or known) and

b) on close analysis, societal forces and players often disagree with each other about their conflicting demands on education (e.g., democratic participation may demand social equality while upward social mobility may demand social inequality, cf. Labaree, 1997).

Second, we strongly argue that outside social forces and players must NOT impose their demands on education via financial resources, regulations, and policies beyond the safety and legal protection concerns for students and education providers for the reasons stated above. They also should be concerned with preservation of the overall educational pluralism and educational opportunities.

Third, outside social forces and players can and even should legitimately set safeguards and establish summative assessments, aiming at sorting education alumni based on their competencies. However, these safeguards and impositions should be done outside of education. Outside social forces and players may want to communicate about the consequential importance of their demands directly to the students or through education providers. They also can be legitimate competence safeguards of the practice. However, it is up to students (mediated by guardians for young and psychologically disabled students) to attend or not to attend to these social demands (which can be wrong in the long-run anyway). The priority of educational curriculum - what to study - has to be always under control of a student (the latter is our partisan DDEFFAA view, of course; a particular student may disagree with that giving the control for his/her curriculum to somebody else).

6.2. Q: Wouldn't your educational pluralism undermine educating a well-rounded person at least for some schools who choose not to push all academic curricula?

A: We always have two positions: One is pluralistic and the other one is our visionary position. According to our pluralistic position, if students and educators want to do education to be a "well-rounded person" this is fine within our proposal. But if not, then they should not.

The other is our partisan position, Democratic Dialogic Education From and For Authorial Agency. According to that position, the "well-rounded" pedagogical objective is both unachievable and undesirable. It is unachievable because human agency cannot exist in a decontextualized, "all purpose", passive, "wait-to-be-used", universal, "do-it-all" form. Human agency is always focused, specialized, purposeful and relational to particular personal desires and situations. In this view, it is impossible, and even harmful to teach subject matters or skills that are not within the student's actual "here-and-now" interests (personally persistent or emergent), and meaningful and important aspects of a practice, in which he or she is involved. All alive creatures have biases in order to be alive. They are attracted to certain things in the environment and repelled from others. Forcing them to become "well-rounded," means making them indifferent and, thus, dead, - killing their interests, attractions, and inquires!

Furthermore, in reality, on a closer look, the so-called "well-rounded curriculum" programs are not so well-rounded, prioritizing a high culture over a low culture, intellectual labor vs. manual labor, well- paid vs. low-paid jobs and professions, and so forth.

A "well-rounded" person, a so-called "a Renaissance man," as a pedagogical goal, is also undesirable. Human agency is at its strongest, most satisfying and most creative when it is well focused and spirited in particular practices. Achieving mastery in one area is always done at expense of another area and, thus, handicaps it. The reverse is also usually true: a handicap in one area of human mastery 
can become an advantage in another area (e.g., colorblind people are good in uncovering military camouflaged weapons and troops ${ }^{14}$ ). Any personal investment in one area of human mastery comes at expense of another. Trying to achieve everything often leads to mediocrity in all fields.

6.3. Q: Don't we need a common educational base? A common cultural capital (Hirsch, Trefil, \& Kett, 1988)? Is there no value in providing all students with the same foundation of knowledge, the basics? Even some required minimum? The common core curriculum? Shouldn't all students know about George Washington or Rosa Parks (in the US context), or to be able to read, or to appreciate "Romeo and Juliet", or to be able to do basic math, algebra, and financial literacy, and to understand statistical information presented in newspapers?

A: Based on our pluralist position, if some students and teachers want to implement a "common core of knowledge" and similar ideas that will be perfectly fine.

Our partisan position as the proponents of Democratic Dialogic Education From and For Authorial Agency however, opposes the educational notion of a "common core knowledge" because it undermines a person's freedom of learning choice. One has to have a freedom of learning choice of what to study, when to study it, with whom, and for what purpose to study it. Freedom of learning choice is an all-ornone position and it comes with the freedom not to study anything that the person does not desire. "Freedom is indivisible. It means you must never influence the choices children make. It's all or nothing" (Neill, 1960). Not only it is unnecessary to require a "common core of knowledge", but also it undermines the "absolute trust" (Neill, Summerhill) in child's agency. Human agency does not recognize decontextualized, pre-existing, personally non-significant knowledge as genuine knowledge.

Not learning something, as a young child, admittedly, can be a handicap for the adult in the child's future. A person might wish to have learned something before. But, the greatest gift that education can give a person is to be open to learning when the person needs it. Preparation for unknown future occurs through the person's intense interaction with the present.

\section{Libertarians' concerns: "The State who pays the piper, calls the Education tune"}

7.1 Q: Are you too naïve and too optimistic to expect benevolence and self-restrain from the State not to engage itself in regulation and defining Educational Philosophy for education the State pays? Are you saying that as long as the state is regulating educational forms that act outside of accordance with the law, then this is sufficient to justify such legislation? Really, at some point, allowing the State to stomp out all educational forms that engage in activities it has judged (by legislation) to be corrosive to order and peace REALLY puts the idea of educational neutrality by the state at risk. In some states - most closely, Canada - it is illegal to engage in holocaust denial, but it is not clear that because states feel that this is pertinent to national security (or, really, civic well-being), that stamping out all educational forms that teach the practice of holocaust denial (not about holocaust denial) is not just run-of-the-mill viewpoint discrimination. Would you place a GREAT bit of faith (ironically enough) in the State to restrain its own powers and hold to a distinction (between regulating for public safety BUT NOTHING ELSE) that is delicate AT BEST?

A: We think we are not as naïve as to assume that just because the State's Educational Neutrality will be morally and legally recognized and accepted by the society in the future (unfortunately, currently, we are far from that yet), it will be enough for the State to behave in accordance with this principle. There are the following several reasons that we doubt in the State's automatic compliance:

1. There will be always grey areas between the legitimate and illegitimate interference of the State using its protective and supportive regulatory power that may interfere with the State Educational Neutrality principle. These grey areas will require case-by-case judgments, which will be contested across diverse

${ }^{14}$ See http://www.time.com/time/magazine/article/0,9171,772387,00.html.

Dialogic Pedagogy: An International Online Journal | http://dpj.pitt.edu DOI: 10.5195/dpj.2016.170 | Vol. 4 (2016) 


\section{Radical Proposal for Educational Pluralism and the State's Educational Neutrality Policy}

Eugene Matusov, Ana Marjanovic-Shane

communities and across time.

2. Different communities and individuals may have both legitimate and illegitimate interests in imposing Educational Philosophies on each other through use of the Oppressive State power. The examples of polygamy in US, holocaust denial in Canada, 2012-2013 failed attempts to regulate the size of "junk drinks" in New York City by Major Blumberg, and so on are very good ones.

3. Unfortunately, the pure abuse of and corruption by power based on the limitless based on the motto, "We can therefore we will," will be with us regardless people in power. We agree with political libertarians and anarchists and the Founders of the USA Republic that it is much better to expect and normalize this evil intend of power abuse even in good folks and develop processes and structures counteracting it as much as possible rather than expect automatic goodness from all people. As history shows again and again, the expectation of the universal goodness from all "good folks" universally leads to terror (e.g., Revolutionary France, Russia, China, and so on).

Although we are not scholars of the Statehood, we have found the current situation and practices in liberal democratic states are more or less satisfactory and being "good enough." This success is based on having many sources of power, diversification of the nature and types of power, divisions of power, vertical and horizontal power, self-correcting processes, freedom of public speech, diverse institutional and informal power, and so on. What liberal democratic society can or cannot legally tolerate remains contested and negotiated. There have been hopeful historical trends of liberalization of the USA and other liberal democratic societies (e.g., gay marriage, open gay military service, gender equality, legalization of marijuana, decriminalization of prostitution, race civil rights). In short, in many ways, we think the situation with the State Educational Neutrality is not unique challenge for a liberal democratic State. It is a challenge along with many other challenges. And we think that a historically liberal democratic State will deal with these challenges in a "good enough" way (and increasingly better). We do not expect and do not want "the perfect" solution for a liberal democratic State. Nothing is guaranteed in a liberal democratic State - even such an arguably unproblematic issue as a State's ban on torture can suddenly become an issue of a public political debate (e.g., in the 21 st century in the USA). Deeply down, the society is regulated by consciences of its participants and not just by its laws and Constitution (Dershowitz, 2002). Everything remains problematic and contested and will remain contested. For example, although the State and the Church are constitutionally separated in the USA, the relationship between the State and the Church remain problematic and this is not necessary a bad thing. We expect that the relationship between the State and the Education will remain bumpy under our revolutionary proposal of the State Educational Neutrality.

In our revolutionary proposal insisting on providing the minimum financial resources for Good Enough Education by the State to all as a Human Right, we challenge a rather common (wrong) assumption that the State may have additional moral and legal rights in areas of practice and life where the State redistributes taxpayers' funds. In our view, the State's moral and legal rights, when these rights exist legitimately, must be independent of the fact whether a State contributes the taxpayers' money or not. For example, if a State finds out that a particular medicine is poisonous or useless, it should legitimately ban by force this medicine regardless whether the State financially contributes or not to the pharmaceutical industry. Unfortunately, currently this important principle is not widely recognized by the public and by moral and legal foundations of a liberal democratic State. Redistribution of taxpayers' money does not give any additional moral or legal right to the State to interfere. Publically funded enterprise does not give any additional right to run this enterprise. Publically and privately funded enterprises and practices must be regulated in the same way, essentially remaining autonomous, sovereign, and independent from the State. Only State-run enterprises can be different in this regard. This is important for all practices but, especially, important for Education for the following reason.

Based on our Partisan DDEFFAA position, we argue that education has its unique feature of being praxis of praxis, in which defining what "Good Education" is a necessary part of "Good Education" for its participants. This provides additional demand for the State Educational Neutrality in contrast to other practices and enterprises. 
In general, we accept the double nature of the State: the State being a safeguard and enabler of Liberalism and Democracy AND, at the same time, being one of the biggest threats and abusers of Liberalism and Democracy. Unfortunately, in our view, these two tendencies are inseparable and we need to maximize the former and minimize the latter. This is why we are not Political Anarchists or Political Libertarians. We are not for minimization or elimination of the role of the State. But we are not Political Socialists either, hoping that the State will be able to solve all or even major societal problems, either.

Finally, we want to emphasize that the State Monopoly is not the only threat for the Educational Pluralism. Private and public universities, embedded in the capitalist market economy, have managed to establish their own Educational Monopolies without much help by the State, at least in the USA. The Higher Education has been monopolized without support of the State and within the capitalist market forces. We must use legal, moral, formal, and informal diverse types of powers on diverse levels to promote the Educational Pluralism and to resist Educational Monopolies regardless their origin.

\section{Contradictions in your Proposal for the Educational Pluralism}

8.1 Q: Why doesn't your "revolution proposal" for the State's Educational Neutrality apparently work in Higher Education? University and college students have their "private vouchers" to pay tuition but it does not lead to negotiation of pedagogy and curriculum and does not create "a self-correcting practice." Why is that? The institutions of Higher Education remain to be monopolists of defining education for their students and in-tune to the State Monopoly. Why doesn't your proposal work for Higher Education?

A: We agree that Higher Education is monopolized by a technological Standards-Based Educational philosophy similar to the State's Educational Monopoly but using a different means for this monopoly. The current monopoly on educational philosophy by the State is established through funding and regulations - by dictating educational values through public vouchers usually send to the school districts, through regulations, and through accountability policies. In contrast, the Higher Education Monopoly is realized in the US mostly through universities and colleges requiring/forcing students to take particular courses for their successful graduation to get educational credentials valued by businesses and institutions outside of education (i.e., diplomas, certificates, degrees). This conveniently ensures that professors always will have enough number of students in their required classes and release them from anxiety about whether their class will make it or not. These professors do not need to advertise their course to students, or to convince their potential students in value of the course for them, or to be concerned about their teaching reputation among the past, current, and future students. Thus, students cannot vote by their feet (and, thus, tuition dollar) when they find a course or a professor to be insensitive for their educational needs. Also, increasingly the State interferes in Higher Education by imposing its educational standards.

Our Proposal forbids universities and colleges, accepting public educational neutrality vouchers, to dictate students what particular courses they must take for successful graduation. This is one of many possible legitimate regulative state safeguards against educational monopoly by educational providers. Although, in our view, it may be OK for universities to set a minimum number of courses for graduation and their general nature as well as particular non-course learning experiences (e.g., theses defense, internships). We think that forbidding universities, accepting educational neutrality voucers, to force the students to sign up for classes that the students may not want to take will take care of the problem, destroy Higher Education Monopoly on educational philosophy, promote students-professors-employers negotiation of pedagogy and curriculum, make professors answerable to their students, and, thus, democratize professional and liberal Higher Education. We hope that it will also force to take any "experts" of accreditation and professional guilds out of business of dictating pedagogy and curriculum to universities and colleagues. 


\section{Radical Proposal for Educational Pluralism and the State's Educational Neutrality Policy}

Eugene Matusov, Ana Marjanovic-Shane

8.2 Q: There is an apparent contradiction between your Educational Pluralism and your own current version of your particular educational position for "the best education" that you have defined as "Dialogic Education For Agency" (DDEFFAA) (e.g., currently in your classes you are imposing your dialogic values on your students through your DDEFFAA educational practices). Can you address it, please?

A: We think that there is a real tension between our Educational Pluralism and our Particular Educational approach, Democratic Dialogic Education For and From Authorial Agency (DDEFFAA), as "the best educational approach," which we have been developing now. Although DDEFFAA is pregnant with educational pluralism in itself - in a sense it values diverse ideas, desires, and values; - it is true that DDEFFAA also tacitly, but forcefully, socializes the participants in critical dialogue. In our view rooted in Bakhtinian (1999) dialogic framework, the forceful power of socialization in critical dialogue comes from the dialogic nature of humanity. When a teacher is genuinely interested in a student's ideas, feelings, desires, values, opinions, and goals - not to exploit the student's subjectivity, not to "teach" the prescribed curricula, but to understand the student and take the student seriously as another human being, - this interest of one person in another often creates power of dialogic ontological engagement and later even nostalgia for critical dialogue in a student (i.e., "education for nostalgia", although not any nostalgia is good, in our partisan view, - only one about critical dialogue. For example, nostalgia for totalitarian camaraderie is not necessarily good in education).

Our Partisan DDEFFAA educational approach seems to be rooted in Socrates' statement that "unexamined life is not worth living". This statement is a contested statement. Thus, Kukathas (2003) convincingly argues that:

1. unexamined life may be worth living;

2. examined life may not be worth living;

3. examining life may ruin "good life" as defined by the criterion of "living according to one's conscience";

4. imposing examining life on others may deprive them from both their "good life" and their meaningful examination of their lives.

We recognize a contradiction between our Particular Educational DDEFFAA approach and our Educational Pluralist approach and we are committed to both (which means we are committed to a contradiction). Although, we claim that DDEFFAA is better than any other educational approach, we also recognize that education is a self-defining endeavor for the students (i.e., praxis of praxis), which means that students have to be on a path of defining their own education - even if this path is not DDEFFAA. We argue that DDEFFAA's critical dialogue has to be critical to all values, including the value of critical dialogue itself (Matusov \& Lemke, 2015).

\section{Conclusion}

We think that currently the educational and non-educational global has illegitimately taken over the educational local in the modern institutionalized educational practices. The global imposes the educational monopoly over the local via the standards-based education. We see the solution not in changing the particular educational content of this educational monopoly, but rather to declare global educational neutrality. We see the legitimate role of the global in education in promoting educational pluralism and access to good education for all as a fundamental human right.

We see the educational role of the State in:

1. Promoting financial conditions for the minimum human right of the universal access to good education as defined by students;

2. Safeguarding of educational philosophical pluralism;

3. Safeguarding of students' educational interests;

4. Safeguarding of democracy in the society, which at times may interfere with the goal of education. 


\section{Radical Proposal for Educational Pluralism and the State's Educational Neutrality Policy}

Eugene Matusov, Ana Marjanovic-Shane

We do not think that the education has to be in the business of creation of "the social cohesion agenda of education" (Bekerman, Ben Peretz, \& Zisenwine, 2013) and/or "diverse groups' integration" and/or nation-state building. Rather we argue that defining goals and quality of education belong to the local, private, sphere and is the primary business of education itself (Dahlberg \& Moss, 2005; Neill, 1960). Furthermore, we argue that freedom of defining and pursuing one's own education is a part of any liberal project along with freedom of speech, freedom of conscience, freedom of assembly, and freedom to leave any assembly. We argue that freedom of defining and pursuing one's own education is a part of any liberal project along with freedom of speech, freedom of conscience, freedom of assembly, and freedom to leave any assembly. We are against balancing the forces of the global and the local but rather for prioritization of the local in defining education. In our view, education is always local and personal. We respectfully disagree with the goal of education as "creating shared meanings, while validating diversity, which is a pre-condition to securing the world guaranteeing our co-existence" (Bekerman, et al., 2013). Rather, we think that the goal of education has to remain open, negotiated, and contested, being the object education itself. We encourage readers to read our full-scale educational pluralism proposal and more discussion of it here: (http://diaped.soe.udel.edu/SEN) to engage in its critical dialogue.

\section{Appendix: Calculating public educational neutrality voucher amount for minimum good education}

Let us start calculating public educational neutrality voucher amount for minimum good education with providing an incomplete formula of the public Education Funding per Student (EFpS) based on the US situation:

EFpS = Federal Voucher + State Voucher + Local Government Voucher + Grants + Public sources + Parent investment;

Federal Voucher per student= the same amount for all students in the US based on federal taxes (the only amount that is the same for all students);

State Voucher per student= the same amount for all students of a particular state but different among states, based on state taxes;

Local Government Voucher per student= the same amount for all students of a particular locality but different among localities, based on local taxes;

Grants per student = public (=taxes) and/or private money provided for certain causes or conditions that a particular student gets - can be different for across different places or students;

Public sources per student $=$ involve public sources of education (e.g., publically financed Internet sources, Internet infrastructure, libraries, public TV and radio, museums) used by a particular student;

Parent investment per student = Parents' and families' contributions to their child's education (e.g., bought books, paid cable TV, travel abroad, paid access to the Internet).

Hence, with exception of the Federal Voucher, all other education finance sources create financial inequalities in education, which may or may not contribute to educational inequalities.

Note: Besides financial contributions to education there are non-financial contributions involving broadly defined cultural practices (e.g., parents' bed night reading, parental cultural practices of constant discussions and justifications their decisions with their children, learning activism of students, safe and secure state conditions from violence, good general economic conditions, strong public democratic discourse, children free from abuses). Although these non-financial factors may greatly contribute to 


\section{Radical Proposal for Educational Pluralism and the State's Educational Neutrality Policy}

Eugene Matusov, Ana Marjanovic-Shane

education, we do not include them directly in our financial calculation while they may influence indirectly our educational neutrality voucher formula:

1. The minimum sufficient amount of the public educational neutrality voucher will be defined through a special annual survey by an independent agency financed by the State (at each level - Federal, State, and Local governments for the USA).

2. The annual survey will collect and publicize the information about:

a. all students' satisfaction with their education on a 10-point scale (mediated by legal guardian's satisfaction for young and/or psychologically disabled children),

b. we interpret the point 6 out of 10 and above as "good enough education," and

c. all total educational expenses per each student (including all extra contributions by parents, teachers, grants, loans, and so on).

3. We can foresee the following possible scenarios here:

a. "Poorest students" (PS), the students whose education is almost entirely financed by the public educational neutrality vouchers, have the education satisfaction index above or equal 6 on average (PS>=6), no adjustment is necessary. The amount of the educational public voucher seems to be enough to provide the quality of education. There can be a financial investigation for possible decreasing the amount of the 3 Vouchers;

b. "Poorest students" have the education satisfaction index below 6 on average but above "the richer students" (RS), i.e., students whose education funding much exceeds the PS education funding, (RS<=PS<=6), no adjustment is needed. Although students do not seem to access to "the good enough education" on average, funding does not seem to be a factor. We expect that self-correcting processes of students moving away from unsatisfactory education, informed by educational research, will kick in to fix the problem. If the problem persists a special public ad hoc committee is due to investigate the problem (probably along with an academic research);

c. "Poorest students" have the education satisfaction index below 6 on average and below "the richer students" satisfaction index which is below 6 ( $P S<R S<=6)$, adjustment is needed. The adjustment amount for increasing the educational public voucher has to be statistically calculated to allow the average point of the students' satisfaction to reach point 6 , the minimum point defining "the good enough education";

d. "Poorest students" have the education satisfaction index below 6 on average and "the richer students" satisfaction index above or equal 6 (PS $<6<=\mathrm{RS}$ ), adjustment is needed. The adjustment amount for increasing the educational public voucher has to be statistically calculated to allow the average point of the students' satisfaction to reach the average point of the students' satisfaction of their education from the second group.

4. When public educational neutrality voucher has to be adjusted, the Federal Government, State Government, and/or Local County Government have to increase their public educational neutrality voucher amounts, pending on taxpayers' and representatives' willingness, other demands, and priorities.

5. Special education vouchers have to be issued by the Federal Government, State, and Local County regulated by the same principle as described above;

6. All legitimate non-educational functions of the current educational institutions should be separated and financed separately in order not to divert the purpose of education - e.g., babysitting, teenage supervision, preventing children gangs and delinquency, comprehensive immunization, sorting people for proficiency or other purposes (i.e., summative assessments), providing health care, and so on. For example, if a student decides not to get education, his/her 
parents have to be provided by another, non-educational, voucher for some non-educational functions valued by the society;

The transition from funding the current State's Educational Monopoly system based on accountability to funding the new Educational Pluralism system based on self-correcting practice has to be investigated by educational economists and policy analysts. Currently, only students in so-called "public" education schools get taxpayers' money. Will the new system and transition require much more money and taxes? Maybe. On the other hand, although we do not know for sure, our suspicion is that a lot educational money is wasted on bureaucracy, testing, accountability, educational design, textbooks, audits, and so on. The State's current educational monopoly and distrust in students' (and their guardians') educational decision-making are very costly, in our view, in financial, pedagogical, and human agency waste and suffering. We wonder if we do not need to add much money to start the new system (Sidorkin, 2009). The new democratic Educational Pluralism system of self-correcting practice will need minimum bureaucracy for managing educational vouchers. No Boards of Education, no Departments of Education, no publically funded Business Thinking Tanks, no Standardized Testing, no Standardized Textbooks, and so on... Although, some new publically funded agencies of annual surveying, oversight, research, and so on may be needed.

\section{References}

Anderson, M. A. (2010). Investigating the impact of an engaged adolescent participation in Hip-Hop pedagogy: An exploration of the educational possibilities of youth culture. PhD Doctoral dissertation, University of Delaware, Newark.

Arendt, H. (1958). The human condition. Chicago: University of Chicago Press.

Bakhtin, M. M. (1986). Speech genres and other late essays. Austin: University of Texas Press.

Bakhtin, M. M. (1991). Dialogic imagination: Four essays by M. M. Bakhtin (C. Emerson \& M. Holquist, Trans.). Austin, TX: University of Texas Press.

Bakhtin, M. M. (1999). Problems of Dostoevsky's poetics (Vol. 8). Minneapolis: University of Minnesota Press.

Bekerman, Z., Ben Peretz, M., \& Zisenwine, D. (2013). Call for papers: Cultural sustainability, social cohesion and glocal education. Retrieved from http://www.tcrecord.org/Announcement.asp?Announcementld=579

Bolick, C. (2003). Voucher wars: Waging the legal battle over school choice. Washington, D.C.: Cato Institute.

Carl, J. (2011). Freedom of choice: Vouchers in American education. Santa Barbara, CA: Praeger.

Charles, R., Contreras, I., Demuijnck, C., Carranza, P. A., \& Linden, R. (2012). Social cohesion. Retrieved from Social cohesion website: http://www.wikiprogress.org/index.php/Social_cohesion

Collins, A., \& Halverson, R. (2009). Rethinking education in the age of technology: The digital revolution and schooling in America. New York: Teachers College Press.

Dahlberg, G., \& Moss, P. (2005). Ethics and politics in early childhood education. London: RoutledgeFalmer.

Dershowitz, A. M. (2002). Shouting fire: Civil liberties in a turbulent age (1st ed.). Boston: Little, Brown and Co.

Dewey, J. (1915). The school and society (Rev. ed.). Chicago, III.,: University of Chicago press.

Dewey, J. (1966). Democracy and education: An introduction to the philosophy of education (1st Free Press paperback ed.). New York: Free Press.

Ford, M. (2015). Rise of the robots: Technology and the threat of a jobless future. New York: Basic Books. 
Friedman, M. (1955). The role of government in education. In R. A. Solo (Ed.), Economics and the public interest. [Essays written in honor of Eugene Ewald Agger] (pp. 123-144). New Brunswick, NJ: Rutgers University Press.

Glenn, C. L. (1988). The myth of the common school. Amherst: University of Massachusetts Press.

Goldstein, D. (2014). The teacher wars: A history of America's most embattled profession (First edition. ed.). New York: Doubleday.

Goodway, D. (2006). Anarchist seeds beneath the snow : left-libertarian thought and British writers from William Morris to Colin Ward. Liverpool: Liverpool University Press.

Gorz, A. (1989). Critique of economic reason. London: Verso.

Green, A., Preston, J., \& Janmaat, J. G. (2006). Education, equality and social cohesion: Palgrave Macmillan Basingstoke.

Greenberg, D. (1992). The birth of a new paradigm for education. Retrieved from http://www.sudval.com/05_underlyingideas.html\#05

Guterman, N. (1990). The Anchor book of French quotations: with English translations. New York: Anchor Books.

Hall, E. B. (1906). The friends of Voltaire. London: Smith.

Hirsch, E. D., Trefil, J. S., \& Kett, J. F. (1988). Cultural literacy: What every American needs to know (1st Vintage Books ed.). New York: Vintage Books.

Holt, J. C. (1976). Instead of education: Ways to help people do things better (1st ed.). New York: Dutton.

Illich, I. (1983). Deschooling society (1st Harper Colophon ed.). New York: Harper Colophon.

Illich, I., \& Cayley, D. (1992). Ivan Illich in conversation. Concord, Ont.: Anansi.

Kaku, M. (2011). Physics of the future: How science will shape human destiny and our daily lives by the year 2100 (1st ed.). New York: Doubleday.

Keynes, J. M. (1963). Economic possibilities for our grandchildren Essays in persuasion (pp. 358-373). New York: Norton.

Klag, P. (1994). A new look at Invitational Education. The Collaborator, 5(14), 1-2.

Kukathas, C. (2003). The liberal archipelago: A theory of diversity and freedom. Oxford: Oxford University Press.

Labaree, D. F. (1997). How to succeed in school without really learning: The credentials race in American education. New Haven, CT: Yale University Press.

Lauder, H. (1999). Trading in futures: Why markets in education don't work. Buckingham, UK: Open University Press.

Markoff, J. (2015). Machines of loving grace: The quest for common ground between humans and robots. New York: HarperCollins.

Matusov, E. (2009). Journey into dialogic pedagogy. Hauppauge, NY: Nova Science Publishers.

Matusov, E. (2011). Authorial teaching and learning. In E. J. White \& M. Peters (Eds.), Bakhtinian pedagogy: Opportunities and challenges for research, policy and practice in education across the globe (pp. 21-46). New York: Peter Lang Publishers.

Matusov, E., \& Brobst, J. (2013). Radical experiment in dialogic pedagogy in higher education and its centaur failure: Chronotopic analysis. Hauppauge, NY: Nova Science Publishers.

Matusov, E., \& Lemke, J. L. (2015). Values in dialogic pedagogy (Editorial). Dialogic Pedagogy: An International Online Journal, 3, E1-E20. doi: 0.5195/dpj.2015.141

Matusov, E., \& Marjanovic-Shane, A. (2011). The State's Educational Neutrality and Educational Pluralism: A revolution proposal. Retrieved from http://diaped.soe.udel.edu/SEN/

Matusov, E., \& Marjanovic-Shane, A. (2012). Diverse approaches to education: Alienated learning, closed and open participatory socialization, and critical dialogue. Human Development, 55(3), 159-166. doi: 10.1159/000339594 
Matusov, E., \& Marjanovic-Shane, A. (2014). Democratic dialogic education for and from authorial agency: An interview with professor Eugene Matusov. Europe's Journal of Psychology, 10(1), 926. Retrieved from http://ejop.psychopen.eu/article/viewFile/762/pdf doi:10.5964/ejop.v10i1.762

Matusov, E., \& von Duyke, K. (2010). Bakhtin's notion of the Internally Persuasive Discourse in education: Internal to what? (A case of discussion of issues of foul language in teacher education). In K. Junefelt \& P. Nordin (Eds.), Proceedings from the Second International Interdisciplinary Conference on perspectives and limits of dialogism in Mikhail Bakhtin Stockholm University, Sweden June 3-5, 2009 (pp. 174-199). Stockholm: Stockholm University.

Mill, J. S., \& Collini, S. (1989). On liberty; with The subjection of women; and chapters on socialism. Cambridge, UK: Cambridge University Press.

Mouffe, C. (2000). The democratic paradox. London: Verso.

Neill, A. S. (1960). Summerhill: A radical approach to child rearing. New York: Hart Publishing Company. Nicholas. (1954). Of learned ignorance. London: Routledge \& Paul.

Nock, A. J. (1949). The theory of education in the United States ([2nd ed.). Chicago,: H. Regnery Co. Piaget, J., \& Smith, L. (1995). Sociological studies. London ; New York: Routledge.

Pink, D. H. (2005). A whole new mind: Moving from the information age to the conceptual age. New York: Riverhead Books.

Rietmulder, J. (2009). The Circle School: An introduction to integral education ideas and practices. Harrisburg PA: The Circle School.

Rifkin, J. (2014). The zero marginal cost society: The internet of things, the collaborative commons, and the eclipse of capitalism. New York: Palgrave Macmillan.

Rossell, C. H. (1990). The carrot or the stick for school desegregation policy: Magnet schools or forced busing. Philadelphia: Temple University Press.

Sidorkin, A. M. (1999). Beyond discourse: Education, the self, and dialogue. Albany, NY: State University of New York Press.

Sidorkin, A. M. (2002). Learning relations: Impure education, deschooled schools, \& dialogue with evil. New York: P. Lang.

Sidorkin, A. M. (2009). Labor of learning: Market and the next generation of education reform. Rotterdam, the Netherlands: Sense Publishers.

Willis, P. E. (1981). Learning to labor: How working class kids get working class jobs (Morningside ed.). New York: Columbia University Press.

Wolff-Jontofsohn, U. (2013). Berlin: The inner city school initiative "Learning and living diversity (20092012)". Paper presented at the Cultural Sustainability, Social Cohesion and Glocal Education, Jerusalem, Israel.

Zhao, Y. (2009). Catching up or leading the way: American education in the age of globalization. Alexandria, VA: ASCD.

\section{(c) $)$ EY}

New articles in this journal are licensed under a Creative Commons Attribution 4.0 United States License.

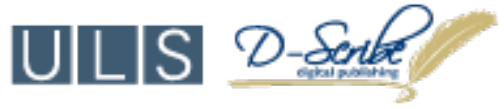

This journal is published by the University Library System, University of Pittsburgh as part of its D-Scribe Digital Publishing Program and is cosponsored by the University of Pittsburgh Press. 